\title{
Pengaruh Latihan Squat Menggunakan Leg Press Stang Barbel Terhadap Kemampuan Angkat Besi pada Atlet Angkat Besi SKOI Kaltim

\author{
Annisa Nur Permata Sholehah
}

S-1 Pendidikan Jasmani, Kesehatan Dan Rekreasi, Fakultas Keguruan dan Ilmu Pendidikan

Universitas Mulawarman

nura63869@gmail.com

\begin{abstract}
ABSTRAK
Penelitian ini bertujuan untuk mengetahui pengaruh latihan squat dengan menggunakan leg press dan latihan squat dengan menggunakan stang barbel terhadap kemampuan angkat besi pada atlet angkat besi SKOI KALTIM. Jenis penelitian ini adalah penelitian eksperimen dengan teknik uji deskriptif, kolmogorov smirnov, homogenitas, paired t-test dan independent t-tes. Populasi dalam penelitian ini adalah seluruh atlet SKOI KALTIM. pengambilan sampel menggunakan sistem simple random sampling terbagi kedalam 2 kelompok yaitu kelompok A latihan squat dengan menggunakan leg press dan kelompok B latihan squat dengan menggunakan stang barbel. Setiap kelompok terdiri dari 10 orang sampel. Jadi jumlah keseluruhan sampel sebanyak 20 orang. Berdasarkan analisis data diperoleh hasil: (1) Ada pengaruh latihan squat dengan menggunakan leg press terhadap kemampuan angkat besi pada atlet angkat besi SKOI KALTIM yang diperoleh nilai $t_{\text {hitung }}=7,000 \geq t_{\text {tabel }}=2,262$ berarti $\mathrm{H}_{1}$ diterima dan $\mathrm{H}_{0}$ ditolak. (2) Ada pengaruh latihan squat dengan menggunakan stang barbel terhadap kemampuan angkat besi pada atlet angkat besi SKOI KALTIM yang diperoleh nilai $t_{\text {hitung }}=9,584 \geq \mathrm{t}_{\text {tabel }}=2,262$ berarti $\mathrm{H}_{1}$ diterima dan $\mathrm{H}_{0}$ ditolak. (3) Tidak ada perbedaan pengaruh latihan squat dengan menggunakan leg press dan latihan squat dengan menggunakan stang barbel terhadap kemampuan angkat besi pada atlet angkat besi SKOI KALTIM yang diperoleh nilai $t_{\text {hitung }}=2,389 \geq t_{\text {tabel }}=2,101$ berarti $\mathrm{H}_{1}$ diterima dan $\mathrm{H}_{0}$ ditolak. Dengan demikian latihan squat dengan menggunakan leg press dan latihan squat dengan menggunakan stang barbel saling memiliki pengaruh yang baik Terhadap Kemampuan Angkat besi pada Atlet Angkat besi SKOI KALTIM.
\end{abstract}

Kata kunci : Latihan Squat, Leg press, Stang barbel, angkat besi, SKOI KALTIM. 


\section{Pendahuluan}

\section{a. Latar Belakang Penelitian}

Kekuatan otot sangat perlu khususnya cabor angkat besi yang memilki tumpuan seluruhnya di anggota tubuh, ada berbagai macam otot yang perlu di latih dan sangat dominan untuk menahan beban yang mungkin dua kali berat badan lifter tersebut. Kekuatan otot tergantung kepada frekwensi serta kekuatan ransangan yang di sampaikan oleh saraf (N.E. Vredensky: 1886). Semakin sering otot di ransang maka semakin kuat otot menahan beban. Semua otot yang ada dalam tubuh sangat berpengaruh dalam proses angkat besi.

Angkat besi terbagi dari tehnik, otot \& kelenturan, semua saling berhubungan, apabila lifter memiliki tehnik dan kelenturan tetapi tidak memilki kekuatan (otot) maka angkatan lifter tersebut tidak akan bisa maksimal. Dalam cabang olahraga angkat besi ada beberapa otot yang dominan di perlukan seperti bahu, dada, punggung/sayap, kaki, dll. Otot yang saling berhubungan dan memiliki peran penting dalam cabang olahraga angkat besi adalah otot kaki.

Otot kaki sangat berperan penting khususnya dalam cabang olahraga angkat besi, otot yang terletak di bagian tubuh bawah ini semestinya harus kokoh untuk menunjang proses terjadinya gerakan dalam angkat besi, agar keseimbangan dapat terjadi dalam proses angkat besi. Untuk membuktikan secara ilmiah maka peneliti mengadakan penelitian dengan judul " Pengaruh bentuk latihan squat dengan menggunakan leg press dan latihan squat dengan menggunakan stang barbel terhadap kemampuan angkat besi pada atlet angkat besi SKOI KALTIM".

\section{b. Tujuan Penelitian}

Berdasarkan rumussan masalah yang telah dikemukakan diatas, maka adapun tujuan penelitian sebagai berikut:

1. Untuk mengetahui apakah ada pengaruh latihan squat dengan menggunakan leg press terhadap kemampuan angkat besi pada atlet angkat besi SKOI KALTIM ?

2. Untuk mengetahui apakah ada pengaruh latihan squat dengan menggunakan stang barbel terhadap kemampuan angkat besi pada atlet angkat besi SKOI KALTIM ? 
3. Untuk mengetahui apakah ada perbedaan pengaruh latihan squat dengan menggunakan leg press dan latihan squat dengan menggunakan stang barbel terhadap kemampuan angkat besi pada atlet angkat besi SKOI KALTIM

c. Manfaat Penelitian

Hasil penelitian ini diharapkan dapat memberikan manfaat antara lain sebagai berikut :

1. Untuk mengembangkan ilmu pengetahuan khususnya yang berkaitan dengan prestasi olahraga angkat besi SKOI KALTIM.

2. Sebagai bahan informasi untuk atlet angkat besi dalam proses berlatih atau belajar, untuk meningkatkan kualitas prestasi atlet SKOI KALTIM.

3. Sebagai data awal pelatih yang dapat di jadikan pegangan untuk mengembangkan prestasi olahraga khususnya angkat besi SKOI KALTIM.

4. Sebagai data awal PABBSI khususnya kaltim untuk mengembangkan prestasi olahraga angkat besi.

5. Sebagai arsip peneliti yang bersifat ilmiah yang dapat dijadikan pegangan.

\section{Kajian Pustakan dan Pengembangan Hipotesis}

a. Angkat besi

Angkat Besi dulu bukan suatu olahraga, melainkan salah satu tontonan dalam pertunjukan sirkus. Angkat Besi dikenal mulai awal abad ke-19. Nama pengangkat besi yang tersohor waktu itu antara lain E. Sandow dan Arthur Saxon dari Jerman, Louis Appolon dari Perancis. Angkat besi pertama kali dapat dilihat di luar arena sirkus pada kejuaraan yang diselenggarakan di London tahun 1891. Setelah itu orang menganggapnya sebagai olahraga, bukan lagi sekedar tontonan. Olahraga ini pertama kali tercatat sebagai cabang olahraga yang dipertandingkan secara resmi pada olimpiade tahun 1896 di Athena, Yunani. Kemudian pada dua 'Olimpiade berikutnya, yakni 1900 di Paris dan 1904 di St Louis, Amerika Serikat, angkat besi juga dipertandingkan. Namun setelah itu angkat besi baru di pertandingkan lagi pada olimpiade tahun 1920 di Antwerpen, Belgia. 
Sebelum perang dunia, Mesir, Perancis dan Jerman selalu merajai arena angkat besi. Setelah itu, Amerika Serikat sering menjadi juara. Tetapi sejak tahun 1953, Uni Soviet dan Bulgaria selalu muncul sebagai pemenang dalam berbagai pertandingan angkat besi di dunia.Hanya pada Olimpiade Los Angeles tahun 1984 nama atlet kedua negara itu tak ada dalam daftar pemenang karena hampir semua negara komunis memboikot Olimpiade itu. Pakaian atlet angkat besi mengenakan pakaian yang umumnya terbuat dari bahan kaus. Ia mengenakan ikat pinggang khusus yang lebar dan tebal di bagian pinggang belakang. Ikat pinggang ini berguna untuk melindungi atlet dari kemungkinan cedera.

\section{b. Jenis Angkatan Yang Dipertandingkan}

1. Snacth

2. Clean \& Jerk

c. Bentuk latihan squat dengan menggunakan leg press

Leg press adalah salah satu latihan untuk melatih paha depan, Latihan ini merupakan bagian dari semua latihan kaki dan sangat membantu bagi mereka yang ingin mendapatkan otot di kaki. Latihan leg press sangat membantu untuk mengembangkan otot kaki bagian atas dan otot panggul sampai batas tertentu. Dalam hal ini untuk menghindari cidera kaki. Posisi tubuh yang benar saat latihan leg press:

1. Letakkan punggung dan kepala anda pada bantalan sandaran alat leg press.

2. Letakkan kedua telapak kaki dan tumit secara secara mendatar, membentyk sudut 90 derajat, selebar bahu/pinggul pada bantalan kak didepan anda.

3. Lutut harus lurus atau sejajar dengan kaki, jangan sampai menekuk ke dalam maupun ke luar.

4. Genggamlah pegangan di samping alat dengan posisi lengan lurus di sisi samping tubuh.

d. Bentuk latihan dengan menggunakan stang barbel

Menurut Frederic Delavier (1995:80) mengatakan, Squat adalah gerakan binaraga nomor satu karena melibatkan sebagian besar system otot. Untuk melakukannya, letakkan barbell di atas rak jongkok. Bebek di bawah mistar dan posisikan di atas bahu anda di atas trapezius dengan agak miring di atas bagian belakang 
deltoids. Pegang bilah menggunakan pegangan lebar yang sesuai dengan tipe tubuh anda dan tarik siku ke belakang.

1. Tarik napas dalam-dalam (untuk mempertahankan tekanan intrathoracic dan mencegah diri dari membungkuk kedepan dan sedikit melengkungkan punggung dengan memutar panggul kedepan.

2. Lihat lurus kedepan dan angkat bilah dari rak.

3. Mundur satu atau dua langkah dari rak dan jadikan kaki selebar bahu, jaga jari-jari kaki mengarah ke depan atau sedikit miring keluar

Dengan bar yang berada di dada, lifter dan beban menurun dalam sikap "low squat". Lutut terlipat secara maksimal, bagian belakang paha menyentuh betis, siku masih ke muka, bahu dalam posisi horizontal. Penting untuk menjaga sikap togok yang benar, yaitu posisi tegak, dengan tulang punggung bagian bawah tidak terlalu melengkung. Titik berat badan berada didepan bahu dan panggul, dan jika diproyeksikan berada di pergelangan kaki. Kesimbangan sama-sama pada kedua kaki. Posisi kepala bebas.

\section{e. Kemampuan Angkat Besi}

Menurut Ma'mun dan Saputra yang dikutip oleh Lukman Baharudin (2016:238) kemampuan gerak dasar merupakan kemampuan yang biasa dilakukan guna meningkatkan kualitas hidup. Kemampuan gerak dasar dibagi menjadi tiga kategori yaitu: Locomotor, nonlocomotor, manipulative

Kemampuan atau mampu dapat diartikan sebagai kekuatan atau kesanggupan. Angkat besi adalah salah satu cabang olahraga yang bersaing untuk mengangkat beban berat yang dinamakan barbel. Berdasarkan teori diatas kemampuan angkat besi adalah kesanggupan seorang atlet untuk melakukan gerakan-gerakan yang berfaktor pada kekuatan, seperti pengertian angkat besi itu sendiri, yaitu mengangkat beban berat. Dalam melakukan gerakan angkat besi ada beberapa faktor komponen fisik yang mempengaruhi kemampuan atlet angkat besi. Komponen kondisi fisik yang dominan digunakan pada cabang olahraga angkat besi yaitu, kekuatan, power, keseimbangan dan kelentukan.

\section{f. Kerangka Berpikir}

1. Melalui latihan squat dengan menggunakan leg press diharapkan mampu meningkatkan kemampuan angkat besi pada atlet angkat besi SKOI KALTIM. 
2. Melalui latihan squat dengan menggunakan stang barbel diharapkan mampu meningkatkan kemampuan angkat besi pada atlet angkat besi SKOI KALTIM

\section{g. Hipotesis Penelitian}

1. Ada pengaruh latihan squat dengan menggunakan leg press terhadap kemampuan angkat besi pada atlet angkat besi SKOI KALTIM.

2. Ada pengaruh latihan squat dengan menggunakan stang barbel terhadap kemampuan Angkat besi pada pada atlet angkat besi SKOI KALTIM.

3. Ada pengaruh latihan squat dengan menggunakan leg press dan latihan squat dengan menggunakan stang barbel terhadap kemampuan Angkat besi pada atlet angkat besi SKOI KALTIM

\section{Metode penelitian}

a. Jenis penelitian

Penelitian ini termasuk dalam jenis penelitian eksperimen. Penelitian eksperimen adalah penelitian yang dilakukan untuk mengetahui ada tidaknya akibat dari sesuatu yang dilakukan pada subyek penelitian, dan berdasarkan dengan hipotesis yang ada maka peneliti ingin mengetahui apakah ada pengaruh latihan squat dengan menggunakan leg press dan latihan squat dengan menggunakan stang barbel trhadap kemampuan angkat besi pada atlet angkat besi SKOI KALTIM.

b. Tempat dan Waktu Penelitian

Penelitian ini dilaksanakan di lapangan Stadion Utama Palaran (Gedung angkat besi) waktu sore hari, mulai jam 16.00 - 17.00 WITA selama 2 bulan.

c. Populasi dan Sampel

Populasi dalam penelitian ini adalah seluruh atlet angkat besi SKOI KALTIM.

\section{d. Tehnik Pengumpulan Data}

1. Tes Kemampuan Angkat besi

Tujuan : Untuk mengukur kemampuan Teknik angkat besi 
Alat/fasilitas :

1) Stang / stick angkatbesi

2) Barbell

3) leg press

4) tiang squat

c. Pelaksanaan test

1) Test melakukan kemampuan tehnik clen $\&$ jerk .

2) Catatan hasil test angkatan.

\section{Hasil dan Pembahasan}

Berdasarkan analisis data diperoleh hasil: (1) Ada pengaruh latihan squat dengan menggunakan leg press terhadap kemampuan angkat besi pada atlet angkat besi SKOI KALTIM yang diperoleh nilai $t_{\text {hitung }}=7,000 \geq t_{\text {tabel }}=2,262$ berarti $\mathrm{H}_{1}$ diterima dan $\mathrm{H}_{0}$ ditolak. (2) Ada pengaruh latihan squat dengan menggunakan stang barbel terhadap kemampuan angkat besi pada atlet angkat besi SKOI KALTIM yang diperoleh nilai thitung $=9,584 \geq \mathrm{t}_{\text {tabel }}=2,262$ berarti $\mathrm{H}_{1}$ diterima dan $\mathrm{H}_{0}$ ditolak. (3) Tidak ada perbedaan pengaruh latihan squat dengan menggunakan leg press dan latihan squat dengan menggunakan stang barbel terhadap kemampuan angkat besi pada atlet angkat besi SKOI KALTIM yang diperoleh nilai $t_{\text {hitung }}=2,389 \geq t_{\text {tabel }}=2,101$ berarti $\mathrm{H}_{1}$ diterima dan $\mathrm{H}_{0}$ ditolak. Dengan demikian latihan squat dengan menggunakan leg press dan latihan squat dengan menggunakan stang barbel saling memiliki pengaruh yang baik Terhadap Kemampuan Angkat besi pada Atlet Angkat besi SKOI KALTIM.

\section{Kesimpulan dan Saran}

Berdasarkan analisis data dan pembahasannya, maka hasil penelitian ini dapat disimpulkan sebagai berikut :

1. Ada pengaruh pada hasil latihan squat menggunakan leg press terhadap kemampuan angkat besi pada atlet angkat besi SKOI KALTIM.

2. Ada pengaruh pada hasil latihan squat menggunakan stang barbel terhadap kemampuan angkat besi pada atlet angkat besi SKOI KALTIM.

3. Ada perbedaan tetapi tidak terlalu signifikan antara latihan squat menggunakan leg press dan latihan squat menggunakan stang barbel terhadap kemampuan angkat besi pada atlet angkat besi SKOI KALTIM.

Berdasarkan kesimpulan penelitian di atas, ada beberapa saran yang dapat diberikan oleh penulis berkenaan dengan hasil penelitian ini adalah sebagai berikut: 
1. Disarankan kepada Pemerintah Daerah khususnya Dinas Pemuda dan Olahraga, agar dapat memperhatikan pembangunan sarana dan prasarana olahraga khususnya pada olahraga angkat besi.

2. Disarankan kepada pembina dan pelatih olahraga khususnya dalam bidang olahraga angkat besi disarankan untuk menggunakan latihan squat dengan leg press dan squat dengan stang barbel terhadap kemampuan angkat besi pada atlet angkat besi SKOI KALTIM.

3. Selain dua latihan diatas, akan lenih baik apabila dalam meningkatkan kekuatan otot paha ditambah dengan latihan-latihan yang lain yang menunjang kemampuan angkat besi agar bisa lebih baik dan sempurna seperti yang diharapkan.

Bagi yang ingin meneliti lebih lanjut tentang olahraga angkat besi agar dapat mencari permasalahan yang lebih dalam dan melibatkan sampel yang lebih banyak lagi, sehingga dapat memperoleh hasil yang lebih baik demi prestasi

\section{Refrensi}

a. Arikunto Suharsimi, 2006, Prosedur Penelitian suatu Pendekatan Praktis, Jakarta: Bina Aksara.

b. A.N. VOROB'EV. 1989. Berlatih tehnik angkat besi. PB PABBSI PT ENKA

c. PARAHIYANGAN.

d. Baechle Thomas R. (dkk) 2007. Bugar dengan Latihan Beban. Jakarta: PT Rajagrafindo Persada.

e. Baharudin, Lukman. (2016). "Hubungan Antara Aktivitas Olahraga Dengan Kemampuan Gerak Dasar Siswa (Studi Pada Siswa Kelas Vi, V dan Vi Sd Negeri 7 Sidokumpul Gresik)". Jurnal Pendidikan Olahraga dan Kesehatan. Vol 4 No. 1 Tahun 2016. Pp. 236241 Fakultas Ilmu Keolahragaan, Universitas Negeri Surabaya.

f. Edi, Setiawan. (2018). "Kontribusi Kelentukan, Kekuatan Otot Tungkai dan Keseimbangan Terhadap Kemampuan Menendang Bola Pada Permainan Sepak Bola Murid SD Inpres Macciniayo Kabupaten Gowa”. Jurnal Pendidikan Olahraga dan Kesehatan. Fakultas Ilmu Keolahragaan Universitas Negeri Makassar.

g. Frederic Delavier, 1995. Strength training anatomy. German: Human kinetics 
h. N.E. Vredensky. 1886 . petunjuk angkat besi .Pb PABBSI.

i. Rahmani Mikanda. 2014, Buku Super Lengkap Olahraga, Jakarta : Dunia Cerdas.

j. Sugiyono. 2016. Metode Penelitian, Bandung : ALFABETA, cv. 